\title{
Article \\ Accessible Educational Resources for Teaching and Learning Robotics
}

\author{
Maria Pozzi ${ }^{1, *(\mathbb{D})}$, Domenico Prattichizzo ${ }^{1,2}$ (D) and Monica Malvezzi ${ }^{1}$ (D) \\ 1 Dipartimento di Ingegneria dell'Informazione e Scienze Matematiche, Università degli Studi di Siena, \\ 53100 Siena, Italy; dprattichizzo@unisi.it (D.P.); monica.malvezzi@unisi.it (M.M.) \\ 2 Istituto Italiano di Tecnologia, 16163 Genova, Italy \\ * Correspondence: maria.pozzi@unisi.it
}

check for

updates

Citation: Pozzi, M.; Prattichizzo, D.;

Malvezzi, M. Accessible Educational Resources for Teaching and Learning Robotics. Robotics 2021, 10, 38. https://doi.org/10.3390/ robotics10010038

Received: 18 December 2020 Accepted: 16 February 2021 Published: 23 February 2021

Publisher's Note: MDPI stays neutral with regard to jurisdictional clai$\mathrm{ms}$ in published maps and institutional affiliations.

Copyright: $(\odot 2021$ by the authors. Licensee MDPI, Basel, Switzerland. This article is an open access article distributed under the terms and conditions of the Creative Commons Attribution (CC BY) license (https:// creativecommons.org/licenses/by/ $4.0 /)$.

\begin{abstract}
Robotics is now facing the challenge of deploying newly developed devices into human environments, and for this process to be successful, societal acceptance and uptake of robots are crucial. Education is already playing a key role in raising awareness and spreading knowledge about robotic systems, and there is a growing need to create highly accessible resources to teach and learn robotics. In this paper, we revise online available educational material, including videos, podcasts, and coding tools, aimed at facilitating the learning of robotics related topics at different levels. The offer of such resources was recently boosted by the higher demand of distance learning tools due to the COVID-19 pandemic. The potential of e-learning for robotics is still under-exploited, and here we provide an updated list of resources that could help instructors and students to better navigate the large amount of information available online.
\end{abstract}

Keywords: robotics in education; human-centered robotics; educational robotics; e-learning; MOOC; online courses

\section{Introduction}

Robotics has considerably improved industrial processes and is expected to soon become an important part of our daily lives, since it has started to face more humancentered problems [1]. Important technological innovations (e.g., the miniaturization of mechatronic components, the development of robust but compliant materials that can be processed by additive manufacturing techniques etc.), as well as relevant advancements in control and learning methods for robots have led to the construction of lightweight robot arms able to effectively co-work with humans [2-4], humanoid robots that can physically and cognitively interface with their surroundings in a human-like fashion $[5,6]$, intrinsically soft robots capable of safely interacting with the environment [7], and wearable robots that can significantly improve the quality of life of impaired people [8]. In other words, robots are starting to be ready to work alongside humans, no longer confined to industrial environments or research laboratories [9]. Are we, humans, ready for collaborating with robots?

The rise of human-centered robotics [1] not only poses questions about the socioeconomical, legal, and ethical impact of robotics on society, but also challenges educational systems to promote and create highly accessible learning and training material on robotics related topics.

Robotics is an interdisciplinary subject whose possible applications involve traditionally separated domains: the engineering domain (e.g., mechanics, electronics, computer science), the human physical domain (e.g., physiology, ergonomics, anatomy), and the human non-physical domain (e.g., psychology, ethics, economy). Even though each discipline addresses robotics from a different point of view and with a different level of detail, establishing a common ground of knowledge (terminology, basic notions, expectations, etc.) could encourage a fruitful discussion and collaboration between such manifold realities. 
The availability of accessible learning resources of different types and with different target audiences is fundamental to reach this aim.

Depending on the individual background and objectives, one can choose to approach the study of robotics in various ways. In this paper, we collect and analyze accessible educational resources that (i) explain basic and advanced robotics concepts through structured on-line courses (Section 3), (ii) inspire audiences through brief talks, tutorials, or podcasts on specific robotics related topics (Section 4), and (iii) allow learning robotics from practical experience (Section 5).

A preliminary version of the literature review was presented in [10], listing only online courses and toolboxes. Here, not only do we expand and update the list of online courses, but we also add other types of educational material and conduct a more detailed analysis of the selected resources in terms of treated topic and target audience. Recently, the main advances in educational robotics, which is an active research area studying devices and methods to teach robotics and with robots, were summarized by Evripidou et al. [11]. In [12], Esposito analyzed the main tools and methods that are used to teach robotics at the university level, including textbooks and software environments, and underlined that only a few instructors rely on online material. In this paper, we focus on online available resources, as we believe that an updated overview of the available educational material on robotics can be beneficial, especially in view of the increased demand for e-learning tools due to the COVID-19 pandemic [13,14].

\section{Methods}

\subsection{Classification Criteria}

The objective of this paper is to provide a possible map for orienting a learner interested in robotics among the heterogeneous amount of material available online. This section illustrates how we selected and classified the resources. As a first step, we divided them into three main sets:

- Resources requiring sequential access;

- Randomly accessible resources;

- Resources for hands-on learning.

The first set of resources is intended to provide the contents typically covered in a course (e.g., in a Master's degree course). Usually, a predefined order has to be followed to fully understand the concepts. Among these resources, we identified two main subsets: Massive Open Online Courses (MOOCs) and lecture series. MOOCs are designed and organized as on-line resources: in addition to video contents, other material is often provided (e.g., text and slides containing additional notions, tests for self-assessment, etc.), and the student is given the possibility to get an official certificate. Lecture series are typically the recordings of lectures held in academic courses, which were originally intended as support material for the course attendees, but thanks to their accessibility, became a useful resource also for students from other universities, or even for the general public.

The second set includes all the resources that can be easily accessed without following a predefined order. They provide small, focused video and/or audio contents that typically can be understood without prior specific knowledge. In this second set, we included YouTube thematic channels, talks from TED and TEDx conferences, and podcasts.

Lastly, we analyzed tools and activities that are useful to learn robotics from practical experience, including robot simulators and robotic competitions.

\subsection{Selection and Inclusion Criteria}

For each type of resource, we adopted different selection and inclusion criteria, as detailed in the following. 


\subsubsection{Resources Requiring Sequential Access}

MOOCs: Our search of MOOCs on robotics started on the Class Central website [15], a well-known search engine for MOOCs, and was then refined by scanning the web pages of the most popular MOOC providers (e.g., Coursera, edX, FutureLearn, etc.). For each identified course, we reviewed the contents and organization, the accessibility, and the costs, and we provided a classification in terms of contents, potential users, and prior knowledge. During the research, we identified courses where robots do not represent the subject, but are the object of the course. For instance, in the course on 3D Model Creation with Autodesk Fusion 360 provided by Coursera [16], the attendee is guided in the design of an Unmanned Aerial Vehicle (UAV), but the focus of the course is the design process, rather than the designed robot. Courses where robots are not the main subject have not been considered in this review for the sake of brevity. In general, we privileged resources in English, as they can be understood by a vast audience. However, in the list of courses targeting school students and teachers (Table A4), we also included MOOCs in other languages, because, in this case, having material in the native language can better support the learning process.

Lecture series: Concerning lecture series, we selected the resources from eminent scientists active in robotics. The courses were selected on the basis of their coherence and completeness. Some of these courses are available on the YouTube platform, and others have a dedicated web page where additional material can be downloaded.

\subsubsection{Randomly Accessible Resources}

Thematic channels on YouTube: YouTube offers collections of videos that are not intended as courses, but provide insightful contents that can be used as teaching and learning material. In this paper, we present some resources that were selected based on prior knowledge, integrated with a specific search on YouTube including the words "robotics", "thematic", and "channels". For each identified resource we evaluated: (i) the coherence of the treated themes, (ii) the quality and originality of the proposed contents, (iii) the number of views and subscribers, and (iv) whether the resource was still active and updated.

Podcasts: Podcasts represent another informative channel that is spreading and getting interest as an integration of learning tools. In this paper, we provide a review of the currently available thematic podcasts regarding robotics. The resources, identified based on prior knowledge and through an additional Internet search, were selected according to the coherence of the contents and the update frequency.

TED talks: Other interesting resources providing insightful perspectives on robotics are TED conferences. The contents of TED talks can be accessed either as videos or as podcasts. In this paper, we reviewed and identified some relevant TED talks that tackle robotics from very different points of view, ranging from technology to psychology, art, and history. The search was carried out on the TED web page [17], and our selection privileged talks with a multidisciplinary perspective.

\subsubsection{Resources for Hands-on Learning}

Programming and building robots: A comprehensive review of educational robotics technological resources for STEM subjects in schools was recently published in [18]. In this paper, we focus on resources that are easily accessible in distance-learning conditions, and we selected a set of software frameworks specific for the academic level. The resources were included on the basis of prior knowledge integrated with a specific online search.

Competitions: Competitions and challenges represent an interesting, but heterogeneous set of activities, whose purposes are different and range from the application of advanced research results by scientists and engineers, to the design and use of educational robots by school students. In this review, we collected the most widely known international competitions, selected on the basis of prior knowledge and integrated with a specific online research, with the aim of highlighting different types of applications and participants. 


\subsection{Preliminary Comparison}

A preliminary overview of and comparison between the types of resources that we analyzed is presented in Table 1. We highlight the required access criteria (sequential or random), the type of provided contents, whether or not it is possible to get credits or certificates, the average level of specialization, and whether or not the payment of a fee is requested. Challenges were not considered in this first comparison.

Table 1. Preliminary comparison between the resources analyzed in this paper.

\begin{tabular}{cccccc}
\hline Resource & $\begin{array}{c}\text { Access } \\
\text { Order }\end{array}$ & Type of Content & $\begin{array}{c}\text { Credits/ } \\
\text { Certificate }\end{array}$ & $\begin{array}{c}\text { General/ } \\
\text { Specialistic }\end{array}$ & Free/ Paid Access \\
\hline MOOCs & Sequential & $\begin{array}{c}\text { Videos, reading } \\
\text { material, tests for } \\
\text { self-assessment }\end{array}$ & Yes & Specialistic & $\begin{array}{c}\text { Typically free access for learning } \\
\text { material, but often require a fee for } \\
\text { getting a certificate. }\end{array}$ \\
\hline $\begin{array}{c}\text { Lecture series } \\
\text { YouTube thematic } \\
\text { channels }\end{array}$ & Sequential & $\begin{array}{c}\text { Videos, reading } \\
\text { material }\end{array}$ & No & Specialistic & Free \\
\hline Podcasts & Random & Video & No & General & Free \\
\hline TED talks & Random & Video and audio & No & General & Free \\
\hline $\begin{array}{c}\text { Tools for } \\
\text { programming and } \\
\text { building robots }\end{array}$ & Sequential & $\begin{array}{c}\text { Software, } \\
\text { videos, reading } \\
\text { material }\end{array}$ & No & Specialistic & Depends on the resource \\
\hline
\end{tabular}

\section{Resources Requiring Sequential Access}

Here, we present currently available on-line courses in the form of Massive Open Online Courses (MOOCs) and video lecture series. Similarly to books and standard school and university courses, these resources require being studied in a sequential order to gradually enter into the subject and acquire knowledge step-by-step, and are taught by worldwide recognized experts in the field. The lists of resources that we found are reported in the tables in Appendix A.

\subsection{Massive Open On-Line Courses}

Massive Open Online Courses (MOOCs) are the most relevant available resources for digital autonomous learning [19]. Since their introduction, the trend of MOOCs' diffusion has been steadily increasing [20]. In 2020, there was a relevant boost in the number of enrolled students in MOOCs [21], mostly as a consequence of the COVID-19 pandemic, which forced nearly 1.6 billion students worldwide to remain at home [22].

MOOCs are usually delivered on global platforms. Those currently having the highest numbers of registered users are Coursera (founded by Andrew Ng and Daphne Koller, Artificial Intelligence Lab, Stanford University), edX (MIT and Harvard), Udacity (a byproduct of Sebastian Thrun's free computer science classes by Stanford University), and FutureLearn (Open University). MOOC platforms not only provide students with educational material, but also allow them to track their progress and to benefit from other services (possibly through the payment of a fee), such as institutional credits, certificates, human tutoring or assignment marking, and proctored examinations.

Almost $30 \%$ of MOOCs available in 2020 teach technology, engineering, or mathematics related topics [21]. We analyzed MOOCs dealing with different aspects of robotics and classified them according to the intended target audience and the treated topic.

Courses developed for university students encompass single courses, as well as specializations, including more than one MOOC (see Tables A1 and A2). Most of the time, these courses require basic knowledge of calculus and physics, and are developed through the collaboration between an online platform and a university. 
It is also possible to find MOOCs addressing school students and teachers (see Table A3). These courses are sometimes delivered in languages different from English (e.g., Spanish, French) and allow learners to familiarize themselves with robotics related concepts or to build and use specific educational platforms. Educational robotics has become an important research area, and several robotic kits have been released in the last few years [23]. In schools, robots can either be the subject of study or the tool through which other subjects are taught [24].

Robotics has already and will continue to have a profound impact on society. Therefore, it is important to create and distribute educational contents related to the ethical, social, and economic implications of the introduction of robots into human contexts. Several MOOCs address this topic (see Table A4), targeting a wide and interdisciplinary public.

Notwithstanding the tools and resources available at different education levels, from the analysis of the state-of-the-art, we realized that only a few online resources are dedicated to the training of professionals and workers. Table A5 includes three MOOCs that go in this direction and target different applications of robots. The first is an introduction to the state-of-the-art and challenges of medical robotics; the second tackles safety standards in collaborative robotics; and the third deals with planning end-to-end missions with drones in agriculture applications. These MOOCs address a specific application domain, but are still far from providing accurate training to operators (e.g., healthcare professionals, surgeons, workmen, etc.) that need to use a certain robotic system to carry out their work. Usually, companies, as well as healthcare facilities organize their own internal courses or collaborate with external public or private institutions to provide workers with the required knowledge to use specific technologies.

\subsection{Lecture Series}

In addition to MOOCs, there are other online resources that can help students learn robotics in a "sequential" way, i.e., lecture series on YouTube or other platforms (see Table A6). These series usually consist of playlists of videos shot during in-person lectures and are offered for free, without the additional services typical of MOOC platforms.

One of the most famous lecture series on robotics is the "Introduction to Robotics" by Prof. Khatib, which has been online since 2008 and is hosted on the Stanford Engineering Everywhere (SEE) website. Furthermore, the lessons by Anarnath have been online since 2008. De Luca recorded and shared both his courses on robotics, and Lynch and Park complemented their book entitled "Modern Robotics" [25] with almost 100 video lectures. Courses on more specific topics include "The Art of Grasping and Manipulation in Robotics" by Prattichizzo et al. (Figure 1), "Programming for robotics (ROS)" by Fankhauser et al., and "Evolutionary Robotics" by Bongard.

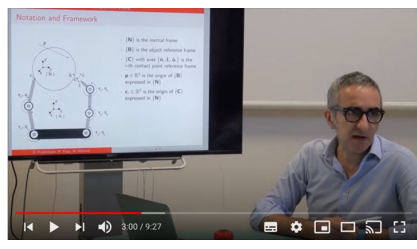

(a)

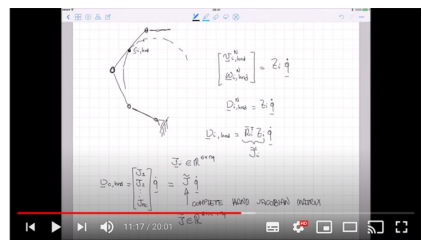

(b)

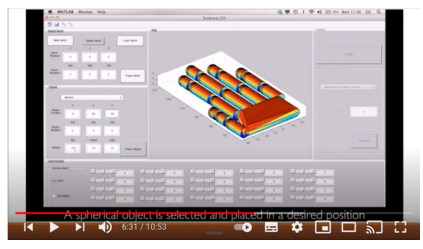

(c)

Figure 1. Three screenshots from the "The Art of Grasping and Manipulation in Robotics" by Prattichizzo et al.: (a) basic definitions, (b) robotic grasp modeling, and (c) simulating robotic grasps with the Syngrasp toolbox [26].

\subsection{Main Topics of MOOCs and Lecture Series}

We identified four main categories of online courses based on the treated topic: robotics foundations, advanced robotics, robot building and programming, and societal impact of robotics. The first one includes lectures that deal with the very foundations of robotics either at a beginner (e.g., "Robotics Specialization" on Coursera), intermediate (e.g., "Modern Robotics Specialization" on Coursera), or advanced level (e.g., "Robotics" on edX). The 
second accounts for courses that focus on specific types of robots or advanced algorithms for robotics. The other two categories include MOOCs and lectures about more practical aspects of robotics and about the challenges that need to be faced for facilitating the societal uptake of robotics. As shown in Figure 2, the majority of available MOOCs and lecture series deal with robotics foundations.

MOOCs and Lecture Series

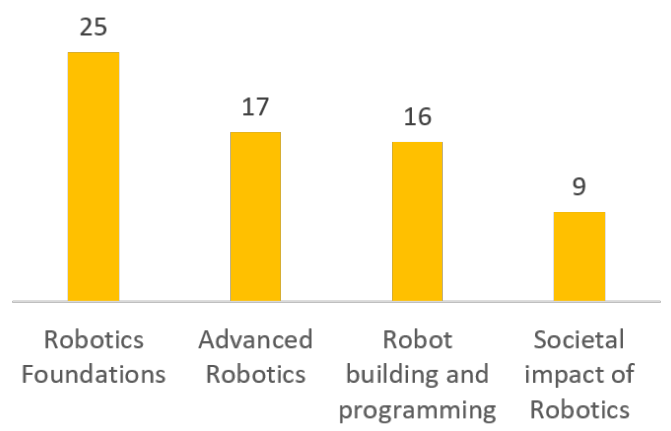

Figure 2. Treated topics of MOOCs and lecture series on robotics. Note that we counted each one of the MOOCs included in specializations as a separate item.

\section{Randomly Accessible Resources}

In this section, we review the main resources on robotics education that can be easily accessed and that do not need to be followed in a fixed sequential order. The Internet has made available a huge amount of informative and educational material in all the knowledge sectors, including videos, articles in magazines and journals, newsletters, podcasts, webinars, etc. These resources provide several opportunities:

- educators can include them in their lectures to clarify concepts that are difficult to understand by traditional means;

- $\quad$ students can integrate their knowledge by themselves;

- anyone can access them to be informed and updated on the topics in which they are interested.

\subsection{Thematic Channels on YouTube}

The use of YouTube videos by STEM instructors is common [27]. Many of them show videos during lectures to explain concepts that are difficult to understand through static images [28]. Although there are some studies analyzing the impact of videos and other technological resources on education, especially in STEM courses, only a small amount of data are available about students' voluntary use of YouTube videos to learn topics taught in their courses.

The problem could be tackled from another point of view, by analyzing the performance in terms of the views and interactions of YouTube videos and channels dealing with science and technology communication. In [29], an analysis of the factors influencing YouTube videos about science communication was performed. The study highlighted the role of the authors (professional-generated contents vs. user-generated contents) and the impact of having a consistent science communication or not. Rosenthal also analyzed, by means of an online survey, the amount of Internet users that watch science videos on YouTube for learning and information purposes [29].

Besides the learning opportunities, the availability of highly accessible partially controlled dissemination videos as the ones available on YouTube could have an impact on how people perceive robots from the psychological and moral points of view [30].

In this study, we analyzed a set of thematic YouTube channels about robots and robotics. The channels that were considered in the analysis were identified as the first ones resulting from a standard web search on the Google search engine and are summarized in 
Table A7, ordered according to their popularity (in terms of number of subscribers). It is interesting to note that eight out of 13 channels are the official communication channels of relevant companies in the robotics community (e.g. Boston Dynamics, Kuka, ABB, etc.), whereas the other ones are user-generated contents. It is also worth mentioning that user-generated channels have the highest popularity ranks: four out of five are within the five channels with the highest number of subscribers (see Figure 3). In addition, four out of five user-generated channels have a clear orientation on providing contents for education and training.

Although the analysis was only partial, it is evident that this type of highly accessible resource represents a concrete opportunity for learning about robotics even outside a structured educational framework.

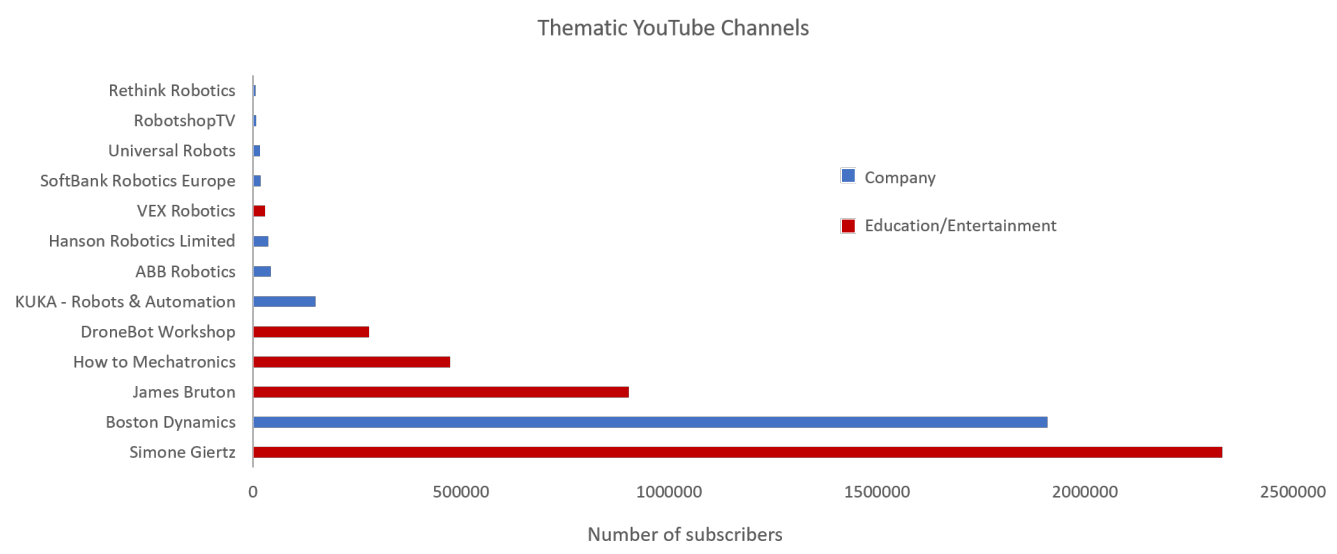

Figure 3. Number of subscribers of the main YouTube channels on robotics.

\subsection{Podcasts}

Podcasts allow people "to listen to what they want, when they want, where they want, and how they want" [31]. This sentence well summarizes the advantages of podcasts and the reasons why they became increasingly popular in the last few years. Podcasting represents an emerging educational tool, and studies on the educational potential of podcasts have been conducted at different levels [32,33]. Podcasting offers the opportunity for lecturers and educators to easily broadcast engaging audio content, which students can then freely listen to at any time and wherever they are. While reading a text or watching a video requires the learner's full attention, podcasts can be listened to during daily activities, including commuting, traveling, driving, taking care of house chores, training at the gym, etc. Podcasts are also useful in cases where visual impairment makes traditional learning methods difficult, or in the case of other difficulties, such as dyslexia. Podcasting is an effective medium for courses where the visual aspect is less important, such as learning a new language. However, it can constitute an additional, auxiliary support element also for scientific and technological courses, including robotics.

In this section, we analyze a set of podcasts available online and dealing with robotics. Although they are designed to be informative channels rather than educational resources, the contents that they present provide basic knowledge concepts, illustrate the current developments and trends, and foster the discussion in multidisciplinary domains. We believe that they can represent a useful medium for people that have little or no experience with robotics to understand the foundations of the subject. There are also more specialized podcasts discussing specific themes, such as soft robotics. The podcasts that we considered were selected according to their accessibility and popularity. Only English resources were included in the analysis. In Table A8, we list the main podcasts that we collected in our survey indicating the treated topics, the time frequency, the year in which they were released for the first time, the last released episode, and their current activity. Regarding the introduction year, it is interesting to note how they are spreading in the last years, and 
especially in 2020: out of 23 analyzed podcasts, 11 (almost 50\%) were released in 2020 (see Figure 4).

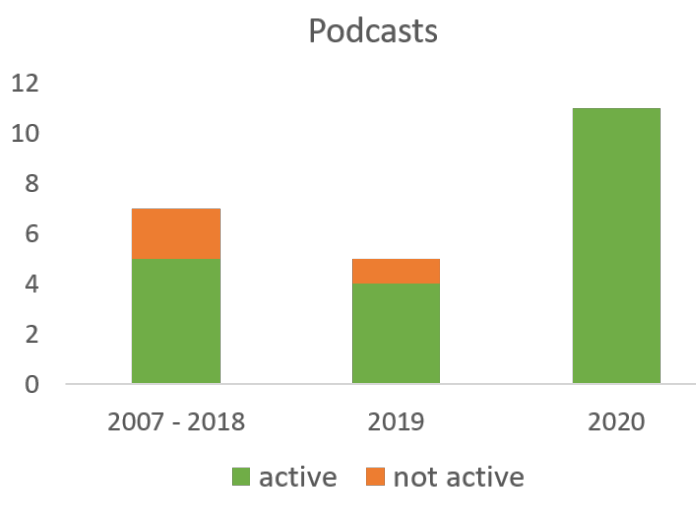

Figure 4. Year of release and status (active/not active) of the main podcasts on robotics.

\subsection{TED Talks}

TED's (Technology, Entertainment, Design) goal is to spread ideas, usually in the form of short and engaging talks by eminent people covering almost all possible topicsfrom science to business to global issues. TED talks are available in more than 100 languages and have been acknowledged as effective educational tools in different application fields [34-36]. Besides TED's main conferences, many independent events named TEDx have been organized worldwide to help share ideas in communities around the world (Figure 5).

Being robotics a cutting-edge technology able to engage and intrigue a wide range of people, often, TED and TEDx conferences include talks by roboticists, scientists, engineers, and experts talking about their latest achievements. The high quality of the presentations, the important role of the speakers in the robotics community, and the accessible and informative language adopted in the presentations make these recorded talks useful resources for introducing robotics. In January 2021, the search for the term "robot" on the TED web page provided 184 talks, 82 people, 25 playlists, and 167 blog posts covering several and very multidisciplinary aspects, ranging from mythology [37], to design [38,39], psychology [40], and art [41]. As a representative and meaningful contribution, it is worth mentioning the talk by Cynthia Breazeal focusing on the complex relationship between humans and robots [42]. Many other talks can be found among the independently organized events (TEDx Talks), accessible through the dedicated YouTube channel.

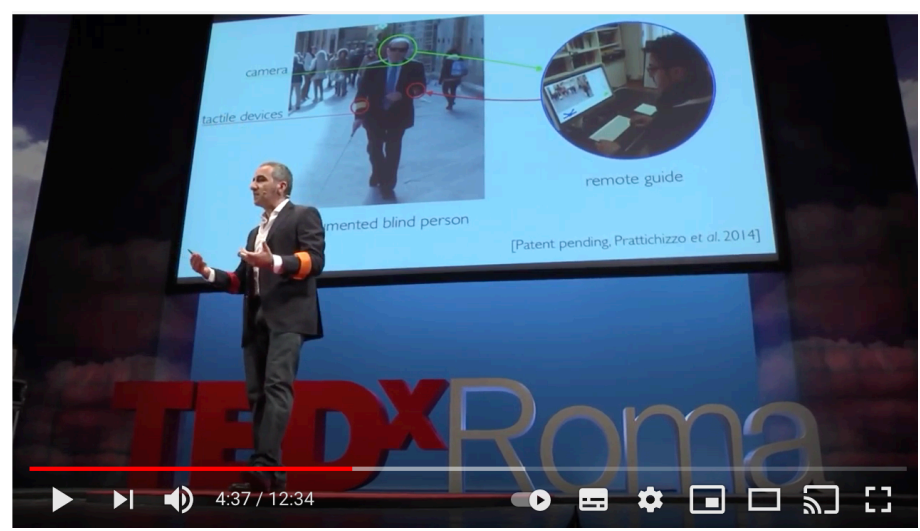

Figure 5. A screenshot from the talk provided by one of the authors at TEDx Roma in 2014 entitled "Wearable technology for the sense of touch". 


\section{Resources for Hands-on Learning}

Learning robotics also means actually building and programming robots. Many of the courses that are listed in Section 3 end with a hands-on hardware and/or software project requiring building and/or programming a robot. There are several available kits and resources for students of different levels [11], but here, we focus on resources designed for distance and self-learning. These include freely available toolboxes and guides for simulating and building robots (Section 5.1).

An important tool to encourage the real-world testing of robotic systems is the organization of competitions. Recently, the most important ones thought for students were summarized by Evripidou et al. [11]. In this paper, we analyze some of them and others more targeted to research groups, focusing on whether the challenge allows also an online participation or not (Section 5.2).

\subsection{Programming and Building Robots}

Several software frameworks have been devised with the objective of teaching robotics, mostly at an academic level. They were recently revised by Cañas et al. [43], who also introduced a new ROS-Based Open Tool for teaching robotics. The use of these platforms usually requires the support of an instructor, or they need to be coupled with structured courses on the topic, as those we present in Section 3. ROS is rapidly entering the educational world. In [44], for example, the development of laboratory exercises using the MATLAB Robotics Systems Toolbox and ROS-enabled robots was presented. One of the most active companies in the field of robotics education through ROS is The Construct [45], which provides both paid and free contents.

Several resources for simulating robots are available online. A very famous toolbox is the MATLAB Robotics Toolbox by Peter Corke [46]. Other examples are SynGrasp [26] and GraspIt! [47], devoted to the simulation of robotic grasping, and ARTE (A Robotics Toolbox for Education), allowing the study of industrial robotic manipulators [48]. Three of the most complete and versatile open-source robot simulators are Webots (Cyberbotics Ltd.) [49], V-REP [50], and Gazebo [51]. These are mostly used for research and education at the university level. Simulators allow students to apply the learned notions in a safe environment, where several analyses can be conducted before actually programming real robots [52].

With the advent of rapid prototyping techniques, building robotic devices has become less expensive and easier, allowing also the development of compliant devices [53]. There are online resources that guide people in the building of robots through illustrated manuals [54] or MOOCs. Despite these tutorials being accessible, most of the time, they require learners to have access to the instrumentation and the components needed to build the devices.

\subsection{Competitions}

Several works on educational robotics report challenges and competitions as an additional tool for robotic education, learning, and training [55].

In [56], the outcomes of the workshop "Robotics Competitions: What Did We Learn?" were summarized. The workshop was organized at the 2015 IEEE/RSJ International Conference on Intelligent Robots and Systems (IROS), and the speakers discussed the role of competitions both in research development and as a way to engage students in science and technology activities.

Challenges and competitions provide stimuli for robotics research, as they allow benchmarking and comparing different solutions, as well as accelerating robot technology and innovation. Relevant examples of challenges in which cutting-edge solutions are presented are the DARPA challenge [57], Cybathlon [58,59], and the Amazon Picking Challenge [60].

Robot competitions are also useful tools to train early career roboticists (e.g., the Student Autonomous Underwater Vehicles Challenge - Europe (SAUC-E) [61,62]) and to 
encourage younger people to enter STEM fields (e.g., the FIRST Lego league [63]). Some of these competitions have a good resonance on media and represent an important tool for promoting robotics to the general public. The YouTube video presenting the funniest fails of robots during the 2015 edition of the DARPA challenge, for instance, has more than 2.5 $\mathrm{M}$ views [64].

Robotic competitions and challenges have been greatly affected by the COVID-19 pandemic, since most of them require the physical presence of participants during the competition. In normal conditions, the event itself is a great opportunity, especially for young students, to meet new teams, exchange ideas, and establish fruitful connections and collaborations. Nevertheless, also among the competitions, new strategies have been found to proceed even with pandemic related restrictions, and, where possible, the events were organized in 2020 in online and/or distance mode. A relevant example of how the competitions have adapted to this new situation is represented by Cybathlon [58], a competition on compensation and rehabilitation devices for people with disabilities that is usually held in Zurich, which in 2020 launched the "Global" edition, with participation from several countries.

A list of the main robotic challenges is reported in Table A9. Notwithstanding the difficulties related to the pandemic, several challenges offer the possibility of participating online or from a distance. Among those that we collected, six out of 12 have this option (see Figure 6).

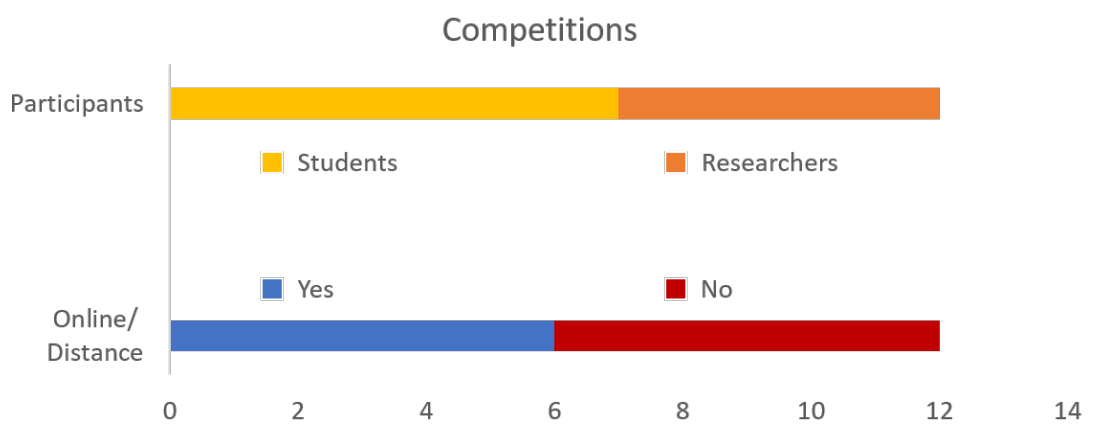

Figure 6. Target participants and participation modes of the main robotics challenges.

\section{Conclusions and Perspectives}

The Internet has made an enormous amount of knowledge accessible and affordable to everyone. However, it is often difficult for learners to orient themselves within all the available resources and to find the ones that are most suitable for their needs, expectations, and background.

In this paper, we propose the classification of some of the most eminent resources for learning robotics. This review can support any person interested in learning robotics for improving and updating his/her skills. For instance, regarding teachers and educational systems, even if the diffusion of robotics educational activities in schools is increasing, it is not yet completely and homogeneously structured: teaching programs are different among different countries and schools. In high schools, often, robotic activities are limited to technological or scientific curricula. The review presented in this paper could, for example, suggest training tools for teachers interested in introducing robots in their courses. The role of on-line resources is becoming increasingly important for undergraduate students and for graduates and PhD students that need to integrate their knowledge. Their diffusion could be improved and optimized through dedicated websites and repositories. More in general, since robots are becoming increasingly important in the everyday lives of many people, initiatives aimed at explaining and debating robotics should be encouraged and promoted. 
Author Contributions: Conceptualization, M.P., D.P., and M.M.; investigation, M.P. and M.M.; methodology, M.P. and M.M.; supervision, D.P. and M.M.; writing, original draft, M.P. and M.M.; writing, review and editing, M.P., D.P., and M.M. All authors have read and agreed to the published version of the manuscript.

Funding: This work was supported by the European Union's Horizon 2020 research and innovation program under Grant Agreement No. 780073-INBOTS (Inclusive Robotics for a Better Society).

Institutional Review Board Statement: Not applicable.

Informed Consent Statement: Not applicable.

Data Availability Statement: No new data were created or analyzed in this study. Data sharing is not applicable to this article.

Conflicts of Interest: The authors declare no conflict of interest.

\section{Appendix A. Resources Requiring Sequential Access}

Table A1. Table summarizing the main MOOCs on robotics for university students with already some basic math and physics knowledge. Here, we list single courses.

\begin{tabular}{|c|c|c|c|}
\hline Title & Instructors & Platform & Link \\
\hline Robot Development & $\begin{array}{l}\text { A. Cangelosi, M. } \\
\text { Schlesinger }\end{array}$ & $\begin{array}{l}\text { edX }(\text { Fed- } \\
\text { ericaX) }\end{array}$ & $\begin{array}{l}\text { https://www.edx.org/course/developmental-robotics } \\
\text { (accessed: 12-2020) }\end{array}$ \\
\hline Robotics & M. Ciocarlie & edX & $\begin{array}{l}\text { https: / / www.edx.org / course / robotics-2?source=aw\& } \\
\text { awc=6798_1579587228_8ab5fe99f95024887456954ee3be136 } \\
\text { 6\&utm_source=aw\&utm_medium=affiliate_partner\& } \\
\text { utm_content=text-link\&utm_term=422873_My+Mooc } \\
\text { (accessed: 12-2020) }\end{array}$ \\
\hline Autonomous Mobile Robots & $\begin{array}{l}\text { R. Siegwart, M. } \\
\text { Chli, M. Hutter, D. } \\
\text { Scaramuzza }\end{array}$ & edX & $\begin{array}{l}\text { https: / / www.edx.org / course / autonomous-mobile- } \\
\text { robots? source=aw\&awc=6798_1579593447_981489d0c8 } \\
\text { ddf5a4d0403d8d1135aaf7\&utm_source=aw\&utm_- } \\
\text { medium=affiliate_partner\&utm_content=text-link\&utm_ } \\
\text { term=422873_My+Mooc (accessed: 12-2020) }\end{array}$ \\
\hline
\end{tabular}

Hello (Real) World with ROS-Robot Operating System

\begin{tabular}{|c|c|c|c|}
\hline Underactuated Robotics & $\begin{array}{l}\text { R. Tedrake, R. } \\
\text { Deits, T. Koolen }\end{array}$ & $\begin{array}{l}\text { edX } \\
(\mathrm{MITx})\end{array}$ & $\begin{array}{l}\text { https://www.edx.org/course/underactuated-robotics-2 } \\
\text { (accessed: 12-2020) }\end{array}$ \\
\hline $\begin{array}{l}\text { Data Management, Data } \\
\text { Security and Robot Operating } \\
\text { System as a Common Tool for } \\
\text { IoT }\end{array}$ & $\begin{array}{l}\text { A. Kapitonov, S. } \\
\text { Distefano, K. } \\
\text { Berkolds, A. } \\
\text { Nikitenko }\end{array}$ & edX & $\begin{array}{l}\text { https:/ / www.edx.org/course / data-management-data- } \\
\text { security-and-robot-operating (accessed: 12-2020) }\end{array}$ \\
\hline $\begin{array}{l}\text { Autonomous Navigation for } \\
\text { Flying Robots }\end{array}$ & $\begin{array}{l}\text { J. Sturm, D. } \\
\text { Cremers, C. Kerl }\end{array}$ & edX & $\begin{array}{l}\text { https://www.edx.org/course/autonomous-navigation- } \\
\text { for-flying-robots (accessed: 12-2020) }\end{array}$ \\
\hline Introduction to Haptics & A. Okamura & edX & $\begin{array}{l}\text { https://www.edx.org/course/introduction-to-haptics } \\
\text { (accessed: 12-2020) }\end{array}$ \\
\hline $\begin{array}{l}\text { Artificial Intelligence for } \\
\text { Robotics }\end{array}$ & S. Thrun & Udacity & $\begin{array}{l}\text { https://www.udacity.com/course/artificial-intelligence- } \\
\text { for-robotics--cs373?utm_medium=referral\&utm_- } \\
\text { campaign=api (accessed: 12-2020) }\end{array}$ \\
\hline $\begin{array}{l}\text { Robots Are Coming! Build IoT } \\
\text { Apps with Watson, Swift, and } \\
\text { Node-RED }\end{array}$ & $\begin{array}{l}\text { M. Sadowski, L. } \\
\text { Frantzell }\end{array}$ & $\begin{array}{l}\text { cognitive } \\
\text { class.ai } \\
\text { (IBM) }\end{array}$ & $\begin{array}{l}\text { https:/ / cognitiveclass.ai/courses/robots-are-coming } \\
\text { (accessed: 12-2020) }\end{array}$ \\
\hline
\end{tabular}

\section{Bharatheesha,}

G. van der Hoorn,

edX

C. Hernandez

https: / / www.edx.org/ course/hello-real-world-with-rosrobot-operating-system (accessed: 12-2020)

Corbato, M. Wisse

A. Kapitonov, S.

Distefano, $\mathrm{K}$.

Berkolds, A.

J. Sturm D.

A. Okamura edX

\section{(}


Table A2. Table summarizing the main MOOCs on robotics for university students with already some basic math and physics knowledge. Here, we list courses that are grouped together either in specializations, or because they are taught by the same professor.

\begin{tabular}{|c|c|c|c|}
\hline Title & Instructors & Platform & Link \\
\hline $\begin{array}{l}\text { Robotics Specialization: Aerial Robotics, Computational } \\
\text { Motion Planning, Mobility, Perception, Estimation and } \\
\text { Learning, Capstone }\end{array}$ & $\begin{array}{l}\text { V. Kumar, C. } \\
\text { J. Taylor, D. E. } \\
\text { Koditschek, } \\
\text { K. Daniilidis, } \\
\text { J. Shi, D. Lee, } \\
\text { S. Deliwala }\end{array}$ & Coursera & $\begin{array}{l}\text { https: / /www.coursera.org/ } \\
\text { specializations / robotics (accessed: } \\
\text { 12-2020) }\end{array}$ \\
\hline $\begin{array}{l}\text { Modern Robotics: Mechanics, Planning, and Control } \\
\text { Specialization: Foundations of Robot Motion, Robot } \\
\text { Kinematics, Robot Dynamics, Robot Motion Planning } \\
\text { and Control, Robot Manipulation and Wheeled Mobile } \\
\text { Robots, Capstone Project-Mobile Manipulation }\end{array}$ & K. Lynch & Coursera & $\begin{array}{l}\text { https://www.coursera.org/ } \\
\text { specializations/modernrobotics } \\
\text { (accessed: 12-2020) }\end{array}$ \\
\hline $\begin{array}{l}\text { Self-Driving Cars Specialization: Introduction, State } \\
\text { Estimation and Localization, Visual Perception, Motion } \\
\text { Planning }\end{array}$ & $\begin{array}{l}\text { S. Waslander, } \\
\text { J. Kelly }\end{array}$ & Coursera & $\begin{array}{l}\text { https://www.coursera.org/ } \\
\text { specializations/self-driving-cars } \\
\text { (accessed: 12-2020) }\end{array}$ \\
\hline Robotics Foundations I-Robot Modeling & B. Siciliano & $\begin{array}{l}\text { edX } \\
\text { (Federicax) }\end{array}$ & $\begin{array}{l}\text { https: } \\
\text { //www.edx.org/course/robotics- } \\
\text { foundations-i-robot-modeling } \\
\text { (accessed: } 12-2020 \text { ) }\end{array}$ \\
\hline Robotics Foundations II-Robot Control & B. Siciliano & $\begin{array}{l}\text { edX } \\
\text { (Federicax) }\end{array}$ & $\begin{array}{l}\text { https://www.edx.org/course/ } \\
\text { robotics-foundation-ii-robot-control } \\
\text { (accessed: 12-2020) }\end{array}$ \\
\hline Electricity \& electronics: Robotics, learn by building & I. Juby & Udemy & $\begin{array}{l}\text { https:/ / www.udemy.com/course/ } \\
\text { analog-electronics-robotics-learn-by- } \\
\text { building/ (accessed: 12-2020) }\end{array}$ \\
\hline Digital Electronics: Robotics, learn by building II & I. Juby & Udemy & $\begin{array}{l}\text { https:/ / www.udemy.com/course/ } \\
\text { digital-electronics-robotics-learn-by- } \\
\text { building-module-ii/ (accessed: } \\
\text { 12-2020) }\end{array}$ \\
\hline Robotic Drives \& Physics: Robotics, learn by building III & I. Juby & Udemy & $\begin{array}{l}\text { https:/ / www.udemy.com/course/ } \\
\text { robotic-drives-and-physics/ (accessed: } \\
\text { 12-2020) }\end{array}$ \\
\hline Introducing Robotics & P. Corke & FutureLearn & $\begin{array}{l}\text { https:/ / www.futurelearn.com/ } \\
\text { programs/robotics (accessed: 12-2020) }\end{array}$ \\
\hline Robotic Vision: Making Robots See & P. Corke & FutureLearn & $\begin{array}{l}\text { https: } \\
\text { // www.futurelearn.com/courses/ } \\
\text { robotic-vision-making-robots-see } \\
\text { (accessed: } 12-2020 \text { ) }\end{array}$ \\
\hline
\end{tabular}


Table A3. Table summarizing the main MOOCs on robotics suitable for school students and/or teachers.

\begin{tabular}{|c|c|c|c|c|}
\hline Title & Instructors & Platform & Link & Language \\
\hline Begin Robotics & R. Miller, W. Harwin & FutureLearn & $\begin{array}{l}\text { https:/ / www.futurelearn.com/ } \\
\text { courses/begin-robotics (accessed: } \\
\text { 12-2020) }\end{array}$ & English \\
\hline $\begin{array}{l}\text { Introducing Robots: Making Robots } \\
\text { Move }\end{array}$ & $\begin{array}{l}\text { P. Corke, E. Pepperel, } \\
\text { O. Lam }\end{array}$ & FutureLearn & $\begin{array}{l}\text { https://www.futurelearn.com/ } \\
\text { courses / making-robots-move } \\
\text { (accessed: 12-2020) }\end{array}$ & English \\
\hline $\begin{array}{l}\text { Introducing Robotics: Build a Robot } \\
\text { Arm }\end{array}$ & $\begin{array}{l}\text { P. Corke, E. Pepperel, } \\
\text { O. Lam }\end{array}$ & FutureLearn & $\begin{array}{l}\text { https://www.futurelearn.com/ } \\
\text { courses/build-a-robot-arm } \\
\text { (accessed: 12-2020) }\end{array}$ & \\
\hline $\begin{array}{l}\text { Robotics With Raspberry Pi: Build } \\
\text { and Program Your First Robot } \\
\text { Buggy }\end{array}$ & A. Parry, N. Szymor & FutureLearn & $\begin{array}{l}\text { https: / /www.futurelearn.com/ } \\
\text { courses / robotics-with-raspberry- } \\
\text { pi accessed: } 12-2020\end{array}$ & English \\
\hline Building Robots with TJBot & J. Bisson, L. Frantzell & cognitiveclass.ai & $\begin{array}{l}\text { https: / / cognitiveclass.ai/ } \\
\text { courses/ build-robots-with-tjbot } \\
\text { accessed: 02-2021 }\end{array}$ & English \\
\hline Robótica (Robotics) & E. Ruiz Velasco & Coursera & $\begin{array}{l}\text { https:/ /www.coursera.org/learn/ } \\
\text { robotica-inicial (accessed: 12-2020) }\end{array}$ & Spanish \\
\hline Scratch: Programming for Teachers & F. Hermans & edX & $\begin{array}{l}\text { https: } \\
\text { //www.edx.org/course/scratch- } \\
\text { programming-for-teachers } \\
\text { (accessed: 12-2020) }\end{array}$ & English \\
\hline $\begin{array}{l}\text { Coding a scuola con software libero } \\
\text { (Coding at school with free } \\
\text { software) }\end{array}$ & A. Formiconi & edX & $\begin{array}{l}\text { https: } \\
\text { // www.edx.org/course/coding- } \\
\text { a-scuola-con-software-libero } \\
\text { (accessed: 12-2020) }\end{array}$ & Italian \\
\hline $\begin{array}{l}\text { Diseña, fabrica y programa tu } \\
\text { propio robot (Design, manufacture } \\
\text { and program your own robot) }\end{array}$ & L. Armesto Angel & edX & $\begin{array}{l}\text { https:/ / www.edx.org/course/ } \\
\text { disena-fabrica-y-programa-tu- } \\
\text { propio-robot (accessed: 12-2020) }\end{array}$ & Spanish \\
\hline $\begin{array}{l}\text { Le robot Thymio comme outil de } \\
\text { découverte des sciences du } \\
\text { numérique (The Thymio robot as a } \\
\text { tool for the discovery of digital } \\
\text { sciences) }\end{array}$ & $\begin{array}{l}\text { F. Mondada, D. Roy, } \\
\text { E. Page, M. Chevalier }\end{array}$ & edX & $\begin{array}{l}\text { https:/ / www.edx.org/course/le- } \\
\text { robot-thymio-comme-outil-de- } \\
\text { decouverte-des-scie (accessed: } \\
\text { 12-2020) }\end{array}$ & French \\
\hline $\begin{array}{l}\text { Die digitale Welt mit dem Thymio } \\
\text { Roboter entdecken (Discover the } \\
\text { digital world with the Thymio } \\
\text { robot) }\end{array}$ & $\begin{array}{l}\text { D. Assaf, J. Dehler } \\
\text { Zufferey, M. Garzi, C. } \\
\text { Giang }\end{array}$ & edX & $\begin{array}{l}\text { https://www.edx.org/course/ } \\
\text { die-digitale-welt-mit-dem- } \\
\text { thymio-roboter-entdecken } \\
\text { (accessed: 02-2021) }\end{array}$ & German \\
\hline $\begin{array}{l}\text { Introducción a la robótica e } \\
\text { industria } 4.0 \text { (Introduction to } \\
\text { robotics and industry } 4.0 \text { ) }\end{array}$ & $\begin{array}{l}\text { L. A. Munos Ubando, } \\
\text { D. A. Sansores } \\
\text { Peraza, D. A. } \\
\text { Sansores Peraza }\end{array}$ & edX & $\begin{array}{l}\text { https://www.edx.org/course/ } \\
\text { introduccion-a-la-robotica-y- } \\
\text { sistemas-para-la-indu (accessed: } \\
\text { 12-2020) }\end{array}$ & Spanish \\
\hline $\begin{array}{l}\text { Fun with Beginner LEGO } \\
\text { MindStorms EV3 Robotics }\end{array}$ & Y. Lu, Y. Chen & Udemy & $\begin{array}{l}\text { https: / / www.udemy.com/ } \\
\text { course/fun-with-beginner-lego- } \\
\text { mindstorms-ev3-robotics/ } \\
\text { (accessed: 02-2021) }\end{array}$ & English \\
\hline $\begin{array}{l}\text { Robots y Videojuegos en las aulas: } \\
\text { Scratch y Arduino para profesores } \\
\text { (Robots and video games in the } \\
\text { classroom: Scratch and Arduino for } \\
\text { teachers) }\end{array}$ & $\begin{array}{l}\text { M. A. Rodriguez } \\
\text { Fernandez }\end{array}$ & Miríadax_ & $\begin{array}{l}\text { https:/ / miriadax.net/web/ } \\
\text { robots-videojuegos-aulas-scratch- } \\
\text { arduino-profesores-3ed/inicio } \\
\text { (accessed: 12-2020) }\end{array}$ & Spanish \\
\hline
\end{tabular}


Table A4. Table summarizing the main MOOCs on the potential impact of robotics and technologies in general on the society.

\begin{tabular}{|c|c|c|c|}
\hline Title & Instructors & Platform & Link \\
\hline $\begin{array}{l}\text { Introducing Robotics: Robotics and } \\
\text { Society }\end{array}$ & $\begin{array}{l}\text { P. Corke, E. Pepperel, } \\
\text { O. Lam }\end{array}$ & FutureLearn & $\begin{array}{l}\text { https:/ /www.futurelearn.com/courses/ } \\
\text { robotics-and-society (accessed: 12-2020) }\end{array}$ \\
\hline Building a Future with Robots & S. Veres & FutureLearn & $\begin{array}{l}\text { https:/ / www.futurelearn.com/courses/ } \\
\text { robotic-future (accessed: 12-2020) }\end{array}$ \\
\hline $\begin{array}{l}\text { Future Robots. Towards a Robotic } \\
\text { Science of Human Beings }\end{array}$ & D. Parisi & edX (FedericaX) & $\begin{array}{l}\text { https: } \\
\text { //www.edx.org/course/future-robots- } \\
\text { towards-a-robotic-science-of-human-b } \\
\text { (accessed: } 12-2020 \text { ) }\end{array}$ \\
\hline $\begin{array}{l}\text { Communicating with Robots and } \\
\text { Bots }\end{array}$ & E. Sandry, G. Peaty & edX & $\begin{array}{l}\text { https://www.edx.org/course/ } \\
\text { communicating-with-robots-and-bots } \\
\text { (accessed: 12-2020) }\end{array}$ \\
\hline $\begin{array}{l}\text { Responsible Innovation: Ethics, } \\
\text { Safety and Technology }\end{array}$ & J. van der Hoven & edX & $\begin{array}{l}\text { https: } \\
\text { //www.edx.org/course/responsible- } \\
\text { innovation-ethics-safety-and-technolog } \\
\text { (accessed: 12-2020) }\end{array}$ \\
\hline $\begin{array}{l}\text { Mind of the Universe--Robots in } \\
\text { Society: Blessing or Curse? }\end{array}$ & $\begin{array}{l}\text { V. Dignum, J. Bieger, R. } \\
\text { Mercuur }\end{array}$ & edX & $\begin{array}{l}\text { https: } \\
/ / / \text { www.edx.org/course/mind-of-the- } \\
\text { universe-robots-in-society-blessing-or } \\
\text { (accessed: 12-2020) }\end{array}$ \\
\hline $\begin{array}{l}\text { SDG: Moving Towards Sustainable } \\
\text { Work }\end{array}$ & $\begin{array}{l}\text { E. M. Blázquez Agudo, } \\
\text { M. G. Quintero Lima, } \\
\text { M. T. Alameda Castillo, } \\
\text { A. B. Munoz Ruiz }\end{array}$ & edX & $\begin{array}{l}\text { https:/ / www.edx.org/course/sdg- } \\
\text { moving-towards-sustainable-work } \\
\text { (accessed: 12-2020) }\end{array}$ \\
\hline Designing the Future of Work & S. McIntyre & Coursera & $\begin{array}{l}\text { https://www.coursera.org/learn/ } \\
\text { designing-future-of-work (accessed: } \\
\text { 12-2020) }\end{array}$ \\
\hline $\begin{array}{l}\text { My Friend is a Robot: Introduction to } \\
\text { Social Robotics }\end{array}$ & N. Zilberman & Coursera & $\begin{array}{l}\text { https:/ / www.coursera.org/learn/moy- } \\
\text { drug-robot (accessed: 12-2020) }\end{array}$ \\
\hline
\end{tabular}

Table A5. Table summarizing the main MOOCs on robotics targeting specific robotics applications.

\begin{tabular}{llll}
\hline Title & Instructors & Platform & Link \\
\hline MedTech: AI and Medical Robots & S. Xie & FutureLearn & $\begin{array}{l}\text { https://www.futurelearn.com/courses/ } \\
\text { medtech-ai-and-medical-robots (accessed: } \\
\text { 12-2020) }\end{array}$ \\
\hline $\begin{array}{l}\text { Collaborative Robot Safety: Design \& } \\
\text { Deployment }\end{array}$ & B. Carlisle, A. Sivadas & Coursera & $\begin{array}{l}\text { https://www.coursera.org/learn/ } \\
\text { collaborative-robot-safety (accessed: } \\
\text { 12-2020) }\end{array}$ \\
\hline $\begin{array}{l}\text { Drones for Agriculture: Prepare and } \\
\begin{array}{l}\text { Design Your Drone (UAV) Mission } \\
\text { L. Kooistra, J. Valente }\end{array}\end{array}$ & edX & $\begin{array}{l}\text { https://www.edx.org/course/drones- } \\
\text { for-agriculture-prepare-and-design- } \\
\text { your-dro (accessed: 02-2021) }\end{array}$ \\
\hline
\end{tabular}


Table A6. Table summarizing the main courses on robotics for university students available as online lecture series.

\begin{tabular}{|c|c|c|c|}
\hline Title & Instructors & $\begin{array}{l}\text { Online } \\
\text { Since }\end{array}$ & Link \\
\hline $\begin{array}{l}\text { Introduction to Robotics } \\
\text { (CS223A) }\end{array}$ & O. Khatib & 2008 & $\begin{array}{l}\text { https: / / see.stanford.edu/course/cs223a (accessed: } \\
\text { 12-2020) }\end{array}$ \\
\hline Lecture Series on Robotics & C. Amarnath & 2008 & $\begin{array}{l}\text { https: / / www.youtube.com/watch?v=DaWMvEY3Qgc\& } \\
\text { list=PL2A735F42FA18D5DD (accessed: 12-2020) }\end{array}$ \\
\hline Robotics 1 & A. De Luca & 2014 & $\begin{array}{l}\text { https: / / www.youtube.com/watch?v=pitZv3PuVMw\& } \\
\text { list=PLAQopGWlIcyaqDBW1zSKx7lHfVcOmWSWt } \\
\text { (accessed: 12-2020) }\end{array}$ \\
\hline $\begin{array}{l}\text { Programming for Robotics } \\
\text { (ROS) }\end{array}$ & $\begin{array}{l}\text { P. Fankhauser, D. } \\
\text { Jud, M. } \\
\text { Wermelinger }\end{array}$ & 2017 & $\begin{array}{l}\text { https:/ / www.youtube.com/watch?v=0BxVPCInS3M\& } \\
\text { list=PLE-BQwvVGf8HOvwXPgtDfWoxd4Cc6ghiP } \\
\text { (accessed: 12-2020) }\end{array}$ \\
\hline $\begin{array}{l}\text { Modern Robotics: Mechanics, } \\
\text { Planning, and Control }\end{array}$ & K. Lynch, F. Park & 2017 & $\begin{array}{l}\text { https: / / www.youtube.com/watch?v=jVu-Hijns70\&list= } \\
\text { PLggLP4f-rq02vX0OQQ5vrCxbJrzamYDfx (accessed: } \\
\text { 12-2020) }\end{array}$ \\
\hline $\begin{array}{l}\text { The Art of Grasping and } \\
\text { Manipulation in Robotics }\end{array}$ & $\begin{array}{l}\text { D. Prattichizzo, } \\
\text { M. Malvezzi, M. } \\
\text { Pozzi }\end{array}$ & 2018 & $\begin{array}{l}\text { https: / / www.youtube.com/watch? } \mathrm{v}=\mathrm{nX} \text { 2SPrambc0 } \\
\text { \&list=PLfYZRHo5ca5aCioiOFcR-ItKhWtmjHA-R accessed: } \\
\text { 12-2020 }\end{array}$ \\
\hline Robotics 2 & A. De Luca & 2020 & $\begin{array}{l}\text { https: / / www.youtube.com/watch?v=HYnE7YgJAxs\& } \\
\text { list=PLAQopGWlIcya6LnIF83Q1JTqvpYmJXnDm } \\
\text { (accessed: 12-2020) }\end{array}$ \\
\hline Evolutionary Robotics & J. Bongard & 2020 & $\begin{array}{l}\text { https: / / www.youtube.com/watch?v=CmiJIKxtEOE\&list= } \\
\text { PLAuiGdPEdwOinlKisMbjDypCbvcb_GBN9 (accessed: } \\
\text { 12-2020) }\end{array}$ \\
\hline
\end{tabular}

\section{Appendix B. Randomly Accessible Resources}

Table A7. Table summarizing the main YouTube channels dealing with robotics.

\begin{tabular}{|c|c|c|c|}
\hline Title & $\begin{array}{l}\text { Subscribers } \\
(12-2020)\end{array}$ & Link & Type \\
\hline Simone Giertz & $2.33 \mathrm{M}$ & $\begin{array}{l}\text { https://www.youtube.com/channel/UC3KEoMzNz8 } \\
\text { eYnwBC34RaKCQ (accessed: 12-2020) }\end{array}$ & Entertainment \\
\hline Boston Dynamics & $1.91 \mathrm{M}$ & $\begin{array}{l}\text { https://www.youtube.com/user/BostonDynamics } \\
\text { (accessed: 12-2020) }\end{array}$ & Robotic company \\
\hline James Bruton & $903 \mathrm{k}$ & $\begin{array}{l}\text { https://www.youtube.com/user/jamesbruton } \\
\text { (accessed: 12-2020) }\end{array}$ & $\begin{array}{l}\text { Education- } \\
\text { entertainment }\end{array}$ \\
\hline How to Mechatronics & $474 \mathrm{k}$ & $\begin{array}{l}\text { https://www.youtube.com/user/DejanNedelkovski } \\
\text { (accessed: 12-2020) }\end{array}$ & Education-DIY \\
\hline DroneBot Workshop & $279 \mathrm{k}$ & $\begin{array}{l}\text { https://www.youtube.com/channel/UCzml9 } \\
\text { bXoEM0itbcE96CB03w (accessed: 12-2020) }\end{array}$ & Education-DIY \\
\hline $\begin{array}{l}\text { KUKA - Robots \& } \\
\text { Automation }\end{array}$ & $151 \mathrm{k}$ & $\begin{array}{l}\text { https://www.youtube.com/user/KukaRobotGroup } \\
\text { (accessed: 12-2020) }\end{array}$ & Robotic company \\
\hline $\begin{array}{l}\text { Hanson Robotics } \\
\text { Limited }\end{array}$ & $37.2 \mathrm{k}$ & $\begin{array}{l}\text { https://www.youtube.com/channel/UCUb1 } \\
\text { bZLNfEbTV1IiDb9kSVw (accessed: 12-2020) }\end{array}$ & Company \\
\hline
\end{tabular}


Table A7. Cont.

\begin{tabular}{|c|c|c|c|}
\hline Title & $\begin{array}{l}\text { Subscribers } \\
(12-2020)\end{array}$ & Link & Type \\
\hline ABB Robotics & $42.2 \mathrm{k}$ & $\begin{array}{l}\text { https://www.youtube.com/user/ABBRobotics } \\
\text { (accessed: 12-2020) }\end{array}$ & Robotic company \\
\hline VEX Robotics & $29.3 \mathrm{k}$ & $\begin{array}{l}\text { https://www.youtube.com/user/vexroboticstv } \\
\text { (accessed: 12-2020) }\end{array}$ & Education \\
\hline $\begin{array}{l}\text { SoftBank Robotics } \\
\text { Europe }\end{array}$ & $18.6 \mathrm{k}$ & $\begin{array}{l}\text { https://www.youtube.com/user/AldebaranRobotics } \\
\text { (accessed: 12-2020) }\end{array}$ & Robotic company \\
\hline Universal Robots & $16.1 \mathrm{k}$ & $\begin{array}{l}\text { https: } \\
\text { // www.youtube.com/user/UniversalRobotsVideo } \\
\text { (accessed: 12-2020) }\end{array}$ & Robotic company \\
\hline RobotshopTV & $7.1 \mathrm{k}$ & $\begin{array}{l}\text { https:/ / www.youtube.com/channel/ } \\
\text { UCEdWTCvrcd-oSjEVq9r2Q3Q (accessed: 12-2020) }\end{array}$ & Company \\
\hline Rethink Robotics & $6.3 \mathrm{k}$ & $\begin{array}{l}\text { https://www.youtube.com/user/RethinkRobotics } \\
\text { (accessed: 12-2020) }\end{array}$ & Robotic company \\
\hline
\end{tabular}

Table A8. Table summarizing the main podcasts dealing with robotics.

\begin{tabular}{|c|c|c|c|c|c|}
\hline Title & Link & Frequency & Since & Active & Audience \\
\hline Robohub & $\begin{array}{l}\text { https://robohub.org/podcast/ (accessed: } \\
\text { 12-2020) }\end{array}$ & $2 /$ month & Jun-08 & yes & general \\
\hline $\begin{array}{l}\text { ROS developers } \\
\text { podcast }\end{array}$ & $\begin{array}{l}\text { https://rosdeveloperspodcast.libsyn.com/ } \\
\text { (accessed: 12-2020) }\end{array}$ & weekly & Jan-18 & yes & technical \\
\hline $\begin{array}{l}\text { Robot report } \\
\text { podcast }\end{array}$ & $\begin{array}{l}\text { https://www.therobotreport.com/category/ } \\
\text { podcast/ (accessed: 12-2020) }\end{array}$ & weekly & Jun-20 & yes & general \\
\hline RobotPsych & $\begin{array}{l}\text { https: } \\
\text { //www.robopsych.com/robopsychpodcast } \\
\text { (accessed: 12-2020) }\end{array}$ & weekly & Jan-15 & yes & $\begin{array}{l}\text { psychology, human } \\
\text { science }\end{array}$ \\
\hline $\begin{array}{l}\text { Soft robotics } \\
\text { podcast }\end{array}$ & $\begin{array}{l}\text { http: } \\
\text { //softrobotics.org/soft-robotics-podcast/ } \\
\text { (accessed: 12-2020) }\end{array}$ & weekly & Aug-19 & yes & technical \\
\hline VECNA robotics & $\begin{array}{l}\text { https://www.vecnarobotics.com/category/ } \\
\text { podcasts / (accessed: 12-2020) }\end{array}$ & weekly & Jul-20 & yes & industrial \\
\hline Exapte & $\begin{array}{l}\text { https://www.exaptec.com.au/podcast } \\
\text { (accessed: 12-2020) }\end{array}$ & daily & Jun-20 & yes & general \\
\hline $\begin{array}{l}\text { The Robot State } \\
\text { Reports }\end{array}$ & $\begin{array}{l}\text { https: / / robotstate.podbean.com/ (accessed: } \\
\text { 12-2020) }\end{array}$ & monthly & Mar-20 & yes & general \\
\hline RoboZone podcast & $\begin{array}{l}\text { https://soundcloud.com/robozonepodcast } \\
\text { (accessed: 12-2020) }\end{array}$ & monthly & Sep-16 & no & general, students \\
\hline $\begin{array}{l}\text { Littler AI, Robotics } \\
\text { and Data }\end{array}$ & $\begin{array}{l}\text { https://soundcloud.com/littler-ai-robotics- } \\
\text { data/tracks (accessed: 12-2020) }\end{array}$ & quarterly & Mar-19 & yes & $\begin{array}{l}\text { legal, ethics, social } \\
\text { aspects }\end{array}$ \\
\hline Robotics assemble & $\begin{array}{l}\text { https: } \\
\text { //blog.feedspot.com/robotics_podcasts / } \\
\text { (accessed: 12-2020) }\end{array}$ & $2 /$ month & Aug-20 & yes & general, students \\
\hline Wake up learn & $\begin{array}{l}\text { https: / / anchor.fm/wakeuplearn (accessed: } \\
\text { 12-2020) }\end{array}$ & quarterly & Jun-17 & yes & general, students \\
\hline
\end{tabular}


Table A8. Cont.

\begin{tabular}{|c|c|c|c|c|c|}
\hline Title & Link & Frequency & Since & Active & Audience \\
\hline $\begin{array}{l}\text { No fear of the } \\
\text { robots }\end{array}$ & $\begin{array}{l}\text { https://anchor.fm/conveyoru (accessed: } \\
\text { 12-2020) }\end{array}$ & monthly & Jan-20 & yes & general \\
\hline $\begin{array}{l}\text { The Robotics } \\
\text { Engineering } \\
\text { Experience }\end{array}$ & $\begin{array}{l}\text { https:/ /anchor.fm/re2robotics / (accessed: } \\
\text { 12-2020) }\end{array}$ & monthly & Jun-20 & yes & general, technical \\
\hline Robot talk & $\begin{array}{l}\text { https://www.ukras.org/RobotTalk/ } \\
\text { (accessed: 12-2020) }\end{array}$ & weekly & Sep-20 & yes & general \\
\hline $\begin{array}{l}\text { The Robot } \\
\text { Industry Podcast }\end{array}$ & $\begin{array}{l}\text { https://therobotindustrypodcast.com/ } \\
\text { (accessed: 12-2020) }\end{array}$ & weekly & May-20 & yes & technical \\
\hline Orange Intelligenz & $\begin{array}{l}\text { https://www.kuka.com/en-us/press/kuka- } \\
\text { robotics-usa-podcast (accessed: 12-2020) }\end{array}$ & monthly & Apr-20 & yes & technical, company \\
\hline Inside the hive & $\begin{array}{l}\text { https:/ / www.listennotes.com/podcasts / } \\
\text { inside-the-hive-bot-hive-KAXHTf4eMps/ } \\
\text { (accessed: 12-2020) }\end{array}$ & quarterly & Jul-19 & yes & general \\
\hline $\begin{array}{l}\text { Learning } \\
\text { Machines } 101\end{array}$ & $\begin{array}{l}\text { https://www.learningmachines101.com/ } \\
\text { lm101-083-ch5-how-to-use-calculus-to- } \\
\text { design-learning-machines / (accessed: } \\
\text { 12-2020) }\end{array}$ & quarterly & Apr-14 & yes & general \\
\hline $\begin{array}{l}\text { Human Robot } \\
\text { Interaction }\end{array}$ & $\begin{array}{l}\text { https://www.human-robot-interaction.org/ } \\
\text { podcast-overview/ (accessed: 12-2020) }\end{array}$ & quarterly & Mar-19 & yes & human sciences \\
\hline Robot in Depth & $\begin{array}{l}\text { https://podcast.wevolver.com/episodes } \\
\text { (accessed: 12-2020) }\end{array}$ & weekly & Sep-19 & no & general \\
\hline Talking Robots & $\begin{array}{l}\text { https://player.fm/series/talking-robots-the- } \\
\text { podcast-on-robotics-and-artificial- } \\
\text { intelligence (accessed: 12-2020) }\end{array}$ & monthly & Jan-07 & no & general \\
\hline The Cobot Show & $\begin{array}{l}\text { https://www.universal-robots.com/ } \\
\text { podcast/the-cobot-show/ (accessed: 12-2020) }\end{array}$ & not regular & May-20 & yes & technical, company \\
\hline
\end{tabular}

\section{Appendix C. Robotics Competitions}

Table A9. Table summarizing the main robotics challenges.

\begin{tabular}{|c|c|c|c|c|c|c|}
\hline Name & Since & Last & $\begin{array}{l}\text { Online/ } \\
\text { Distance }\end{array}$ & Organized by & Type of robots & Participants \\
\hline DARPA Challenge & 2004 & 2018 & no & $\begin{array}{l}\text { Defense Advanced } \\
\text { Research Projects Agency, }\end{array}$ & Autonomous robots & Research groups \\
\hline Cybathlon & 2013 & 2020 & yes & ETH, Zurich & $\begin{array}{l}\text { Rehabilitation and } \\
\text { assistive robots }\end{array}$ & Research groups \\
\hline $\begin{array}{l}\text { MBZInternational } \\
\text { robotic challenge }\end{array}$ & 2017 & 2020 & no & Kalifa University & UAV & Research groups \\
\hline competition ACRE & 2020 & 2020 & yes & Metric project & Agrifood & Research groups \\
\hline $\begin{array}{l}\text { Amazon Picking } \\
\text { Challenge }\end{array}$ & 2016 & 2019 & no & Amazon & Hands and grippers & Research groups \\
\hline SAUC-E & 2006 & 2019 & no & SAUC-e & Underwater robot & Students \\
\hline
\end{tabular}


Table A9. Cont.

\begin{tabular}{|c|c|c|c|c|c|c|}
\hline Name & Since & Last & $\begin{array}{l}\text { Online/ } \\
\text { Distance }\end{array}$ & Organized by & Type of robots & Participants \\
\hline SAUVC & 2019 & 2020 & no & SAUVC & Underwater robot & Students \\
\hline Nao challenge & 2015 & 2020 & yes & Nao challenge & Humanoid robot & Students \\
\hline Zero Robotics & 2009 & 2020 & yes & MIT & Robot programming & Students \\
\hline FIRST Lego League & 2002 & 2020 & yes & Lego & Lego robots & Students \\
\hline Robocup & 1997 & 2019 & no & Robocup & Mobile robots & Students \\
\hline $\begin{array}{l}\text { VEX Robotics } \\
\text { Competition } \\
\text { "Make It Real" } \\
\text { CAD Engineering } \\
\text { Challenge }\end{array}$ & 2017 & 2020 & yes & Autodesk & CAD design & Students \\
\hline
\end{tabular}

\section{References}

1. Siciliano, B.; Khatib, O. Springer Handbook of Robotics; Springer: Cham, Switzerland, 2016.

2. Haddadin, S.; Croft, E. Physical human-robot interaction. In Springer Handbook of Robotics; Springer: Cham, Switzerland, 2016; pp. $1835-1874$.

3. Ajoudani, A.; Zanchettin, A.M.; Ivaldi, S.; Albu-Schäffer, A.; Kosuge, K.; Khatib, O. Progress and prospects of the human-robot collaboration. Autonom. Robot. 2018, 42, 957-975. [CrossRef]

4. Kragic, D.; Gustafson, J.; Karaoguz, H.; Jensfelt, P.; Krug, R. Interactive, Collaborative Robots: Challenges and Opportunities. In Proceedings of the International Joint Conference on Artificial Intelligence (IJCAI-18), Stockholm, Sweden, 13-19 July 2018; pp. 18-25.

5. Cangelosi, A.; Schlesinger, M. Developmental Robotics: From Babies to Robots; MIT Press: Cambridge, MA, USA, 2015.

6. Goswami, A.; Vadakkepat, P. Humanoid Robotics: A Reference; Springer: Dordrecht, The Netherlands, 2019.

7. Eppner, C.; Deimel, R.; Alvarez-Ruiz, J.; Maertens, M.; Brock, O. Exploitation of environmental constraints in human and robotic grasping. Int. J. Robot. Res. 2015, 34, 1021-1038. [CrossRef]

8. Masia, L.; Hussain, I.; Xiloyannis, M.; Pacchierotti, C.; Cappello, L.; Malvezzi, M.; Spagnoletti, G.; Antuvan, C.W.; Khanh, D.B.; Pozzi, M.; et al. Soft wearable assistive robotics: Exosuits and supernumerary limbs. In Wearable Exoskeleton Systems: Design, Control and Applications; Institution of Engineering and Technology: Stevenage, UK, 2018; pp. 219-254.

9. Breazeal, C.; Dautenhahn, K.; Kanda, T. Social robotics. In Springer Handbook of Robotics; Springer: Cham, Switzerland, 2016; pp. 1935-1972.

10. Pozzi, M.; Prattichizzo, D.; Malvezzi, M. On-Line Educational Resources on Robotics: A Review. In Inclusive Robotics for a Better Society. INBOTS 2018. Biosystems \& Biorobotics; Pons, J.L., Ed.; Springer: Cham, Switzerland, 2020; pp. 141-147.

11. Evripidou, S.; Georgiou, K.; Doitsidis, L.; Amanatiadis, A.A.; Zinonos, Z.; Chatzichristofis, S.A. Educational Robotics: Platforms, Competitions and Expected Learning Outcomes. IEEE Access 2020, 8, 219534-219562. [CrossRef]

12. Esposito, J.M. The state of robotics education: Proposed goals for positively transforming robotics education at postsecondary institutions. IEEE Robot. Autom Mag. 2017, 24, 157-164. [CrossRef]

13. Radha, R.; Mahalakshmi, K.; Kumar, V.S.; Saravanakumar, A. E-Learning during lockdown of Covid-19 pandemic: A global perspective. Int. J. Control. Autom. 2020, 13, 1088-1099.

14. Bahasoan, A.N.; Ayuandiani, W.; Mukhram, M.; Rahmat, A. Effectiveness of online learning in pandemic COVID-19. Int. J. Sci. Technol. Manag. 2020, 1, 100-106. [CrossRef]

15. Class Central Website. Available online: www.classcentral.com (accessed on 14 December 2020).

16. 3D Model Creation with Autodesk Fusion 360 (Coursera). Available online: https://www.coursera.org/learn/3d-modelcreation-fusion-360/home/welcome (accessed on 14 December 2020).

17. TED, Ideas Worth Spreading. Available online: https://www.ted.com/ (accessed on 14 December 2020).

18. Sapounidis, T.; Alimisis, D. Educational Robotics for STEM: A Review of Technologies and Some Educational Considerations. In Science and Mathematics Education for 21st Century Citizens: Challenges and Ways Forward; Nova Science Publishers: Hauppauge, NY, USA, 2020; pp. 167-190.

19. De Notaris, D.; Canazza, S.; Mariconda, C.; Paulon, C. How to play a MOOC: Practices and simulation. Entertain. Comput. 2021, 37, 100395. [CrossRef]

20. Class Central. The Report: Your Source for the Latest News and Trends in Online Education. Available online: www.classcentral. $\mathrm{com} /$ report/ (accessed on 14 December 2020).

21. Shah, D. (Class Central). By The Numbers: MOOCs in 2020. Available online: www.classcentral.com/report/mooc-stats-2020/ (accessed on 14 December 2020). 
22. Committee for the Coordination of Statistical Activities. How COVID-19 Is Changing the World: A Statistical Perspective, 2020. Available online: unstats.un.org/unsd/ccsa/documents/covid19-report-ccsa.pdf (accessed on 14 December 2020).

23. Alimisis, D.; Loukatos, D.; Zoulias, E.; Alimisi, R. The Role of Education for the Social Uptake of Robotics: The Case of the eCraft2Learn Project. In Proceedings of the International Conference on Inclusive Robotics for a better Society, Pisa, Italy, 16-18 October 2018; pp. 180-187.

24. Ferrarelli, P.; Villa, W.; Attolini, M.; Cesareni, D.; Micale, F.; Sansone, N.; Pantaleone, L.C.; Iocchi, L. Improving students' concepts about Newtonian mechanics using Mobile robots. In Proceedings of the International Conference on Robotics and Education (RiE 2018), Qawra, Malta, 18-20 April 2018; pp. 113-124.

25. Lynch, K.; Park, F. Modern Robotics: Mechanics, Planning, and Control; Cambridge University Press: Cambridge, UK, 2017.

26. Malvezzi, M.; Gioioso, G.; Salvietti, G.; Prattichizzo, D. SynGrasp: A MATLAB Toolbox for Underactuated and Compliant Hands. IEEE Robot. Autom Mag. 2015, 22, 52-68. [CrossRef]

27. Otchie, W.O.; Pedaste, M.; Bardone, E.; Chounta, I.A. Can YouTube videos facilitate teaching and learning of STEM subjects in high schools? Bull. Tech. Comm. Learn. Technol. 2020, 20, 3-8.

28. Devlin, T.J.; Feldhaus, C.R.; Bentrem, K.M. The Evolving Classroom: A Study of Traditional and Technology-Based Instruction in a STEM Classroom. J. Technol. Educ. 2013, 25, 34-54. [CrossRef]

29. Rosenthal, S. Motivations to seek science videos on YouTube: Free-choice learning in a connected society. Int. J. Sci. Educ. 2018, 8, 22-39. [CrossRef]

30. Küster, D.; Swiderska, A.; Gunkel, D. I saw it on YouTube! How online videos shape perceptions of mind, morality, and fears about robots. New Media Soc. 2020. [CrossRef]

31. Jham, B.C.; Duraes, G.V.; Strassler, H.E.; Sensi, L.G. Joining the podcast revolution. J. Dent. Educ. 2008, 72, 278-281. [CrossRef]

32. Malan, D.J. Podcasting computer science E-1. ACM SIGCSE Bull. 2007, 39, 389-393. [CrossRef]

33. Evans, C. The effectiveness of m-learning in the form of podcast revision lectures in higher education. Comput. Educ. 2008, 50, 491-498. [CrossRef]

34. DaVia Rubenstein, L. Using TED talks to inspire thoughtful practice. Teach. Educ. 2012, 47, 261-267. [CrossRef]

35. Romanelli, F.; Cain, J.; McNamara, P.J. Should TED talks be teaching us something? Am. J. Pharm. Educ. 2014, 78. [CrossRef]

36. Yelamarthi, K.; Drake, E. A flipped first-year digital circuits course for engineering and technology students. IEEE Trans. Educ. 2014, 58, 179-186. [CrossRef]

37. Mayor, A. TED-Ed: The Greek Myth of Talos, the First Robot. Available online: https://www.ted.com/talks/adrienne_mayor_ the_greek_myth_of_talos_the_first_robot (accessed on 19 February 2021).

38. Vause, C. TEDMerck KGaA, Darmstadt, Germany: Meet the Robot Designed Like an Octopus Tentacle. Available online: https: / / www.ted.com/talks/carl_vause_meet_the_robot_designed_like_an_octopus_tentacle (accessed on 19 February 2021).

39. Raibert, M. TED2017: Meet Spot the Robot Dog That Can Run Hop and Open Doors. Available online: https://www.ted.com/ talks/marc_raibert_meet_spot_the_robot_dog_that_can_run_hop_and_open_doors (accessed on 19 February 2021).

40. Darling, K. TED Salon: Why We Have an Emotional Connection to Robots. Available online: https://www.ted.com/talks/kate_ darling_why_we_have_an_emotional_connection_to_robots (accessed on 19 February 2021).

41. Yi, H. TED2017: A Human-Robot Dance Duet. Available online: https://www.ted.com/talks/huang_yi_kuka_a_human_robot_ dance_duet (accessed on 19 February 2021).

42. Breazeal, C. TEDWomen 2010: The Rise of Personal Robots. Available online: https://www.ted.com/talks/cynthia_breazeal_ the_rise_of_personal_robots (accessed on 19 February 2021).

43. Cañas, J.M.; Perdices, E.; García-Pérez, L.; Fernández-Conde, J. A ROS-Based Open Tool for Intelligent Robotics Education. Appl. Sci. 2020, 10, 7419. [CrossRef]

44. Avanzato, R.L.; Wilcox, C.G. Work in progress: Introductory mobile robotics and computer vision laboratories using ROS and MATLAB. In Proceedings of the ASEE Annual Conference and Exposition, Salt Lake City, UT, USA, 24-27 June 2018.

45. The Construct. Available online: https://www.theconstructsim.com/ (accessed on 19 February 2021).

46. Corke, P. Robotics, Vision and Control: Fundamental Algorithms in MATLAB® Second, Completely Revised; Springer: Cham, Switzerland, 2017.

47. Miller, A.T.; Allen, P.K. Graspit! A versatile simulator for robotic grasping. IEEE Robot. Autom Mag. 2004, 11, 110-122. [CrossRef]

48. Gil, A. ARTE: A Robotics Toolbox for Education. Available online: arvc.umh.es/arte/index_en.html (accessed on 10 February 2021).

49. Michel, O. Cyberbotics Ltd. Webots ${ }^{\mathrm{TM}}$ : Professional mobile robot simulation. Int. J. Adv. Robot. Syst. 2004, 1, 5. [CrossRef]

50. Freese, M.; Singh, S.; Ozaki, F.; Matsuhira, N. Virtual robot experimentation platform v-rep: A versatile 3d robot simulator. In Proceedings of the Simulation, Modeling, and Programming for Autonomous Robots (SIMPAR 2010), Darmstadt, Germany, 15-18 November 2010; pp. 51-62.

51. Koenig, N.; Howard, A. Design and use paradigms for gazebo, an open-source multi-robot simulator. In Proceedings of the 2004 IEEE/RSJ International Conference on Intelligent Robots and Systems (IROS), Sendai, Japan, 28 Sepember-2 October 2004; pp. 2149-2154.

52. Yue, H.; Miao, J.; Zhang, J.; Fan, C.; Xu, D. Simulation for senior undergraduate education of robot engineering based on Webots. Comput. Appl. Eng. Educ. 2020. [CrossRef] 
53. Yap, Y.L.; Sing, S.L.; Yeong, W.Y. A review of 3D printing processes and materials for soft robotics. Rapid Prototyp. J. 2020, 26, 1345-1361. [CrossRef]

54. University, H.; Dublin, T.C. Soft Robotics Toolkit. Available online: https://softroboticstoolkit.com/documents (accessed on 16 December 2020).

55. Ribeiro, A.F.; Lopes, G. Learning Robotics: A Review. Curr. Robot. Rep. 2020, 1, 1-11. [CrossRef]

56. Dias, J.; Althoefer, K.; Lima, P.U. Robot competitions: What did we learn? [Competitions]. IEEE Robot. Autom Mag. 2016, 23, 16-18. [CrossRef]

57. Tsagarakis, N.G.; Caldwell, D.G.; Negrello, F.; Choi, W.; Baccelliere, L.; Loc, V.G.; Noorden, J.; Muratore, L.; Margan, A.; Cardellino, A.; et al. Walk-man: A high-performance humanoid platform for realistic environments. J. Field Robot. 2017, 34, 1225-1259. [CrossRef]

58. Riener, R. The Cybathlon promotes the development of assistive technology for people with physical disabilities. J. Neuroeng. Rehabil. 2016, 13, 49. [CrossRef]

59. Perdikis, S.; Tonin, L.; Saeedi, S.; Schneider, C.; Millán, J.d.R. The Cybathlon BCI race: Successful longitudinal mutual learning with two tetraplegic users. PLoS Biol. 2018, 16, e2003787. [CrossRef] [PubMed]

60. Eppner, C.; Höfer, S.; Jonschkowski, R.; Martín-Martín, R.; Sieverling, A.; Wall, V.; Brock, O. Lessons from the Amazon Picking Challenge: Four Aspects of Building Robotic Systems. 2016. Available online: http://www.roboticsproceedings.org/rss12/p36. pdf (accessed on 10 February 2021).

61. Ferri, G.; Ferreira, F.; Djapic, V. Boosting the talent of new generations of marine engineers through robotics competitions in realistic environments: The SAUC-E and euRathlon experience. In Proceedings of the OCEANS 2015-Genova, Genova, Italy, 18-21 May 2015; pp. 1-6.

62. Franchi, M.; Fanelli, F.; Bianchi, M.; Ridolfi, A.; Allotta, B. Underwater Robotics Competitions: The European Robotics League Emergency Robots Experience With FeelHippo AUV. Front. Robot. AI 2020, 7, 3. [CrossRef]

63. Chen, X. How Does Participation in FIRST LEGO League Robotics Competition Impact Children's Problem-Solving Process? In Robotics in Education; Lepuschitz, W., Merdan, M., Koppensteiner, G., Balogh, R., Obdržálek, D., Eds.; Springer International Publishing: Cham, Switzerland, 2019; pp. 162-167.

64. IEEE Spectrum. A Compilation of Robots Falling Down at the DARPA Robotics Challenge. Available online: https://www. youtube.com/watch?v=g0TaYhjpOfo (accessed on 19 February 2021). 